\title{
Correlation between the base of Drumian Stage and the base of middle Caesaraugustan Stage in the Iberian Chains (NE Spain)
}

\author{
ROdOlFo GOZALO, JUAN BAUTISTA CHIRIVELLA MARTORELL, JORGE ESTEVE \& ELADIO LIÑÁN
}

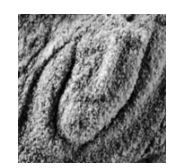

\begin{abstract}
Inter-regional Cambrian correlations are difficult amongst different palaeogeographic provinces, because of a lack of shared genera and species between different palaeogeographic provinces. The Drumian Stage shows this difficulty because it was defined by the FAD of the agnostoid Ptychagnostus atavus, which species has not yet been found in the Mediterranean subprovince. Thus it is necessary to establish a correlation between the ISCS scale and the local scale using other trilobites. New data from the Iberian Chains and a review of previous works suggest that the bases of Pardailhania hispida and Ptychagnostus atavus zones are approximately equivalent. Therefore Pardailhania hispida FAD could be used to mark the beginning of the Drumian Stage in the Mediterranean region. This level is easily identifiable in several places: Montagne Noire (France), Cantabrian Mountains, Demanda Mountains and Iberian Chains (Spain), Sardinia (Italy), Amanos and Sultan Mountains (Turkey), and, probably, Antiatlas (Morocco). $\bullet$ Key words: trilobites, biostratigraphy, Cambrian Stage 5 - Drumian boundary, middle Cambrian / Cambrian Series 3, Mediterranean region.
\end{abstract}

Gozalo, R., Chirivella Martorell, J.B., Esteve, J. \& LiÑán, E. 2011. Correlation between the base of Drumian Stage and the base of middle Caesaraugustan Stage in the Iberian Chains (NE Spain). Bulletin of Geosciences 86(3), 545-554 (8 figures, 1 appendix). Czech Geological Survey, Prague. ISSN 1214-1119. Manuscript received January 3, 2011; accepted in revised form June 15, 2011; published online July 25, 2011; issued September 30, 2011.

Rodolfo Gozalo (corresponding author) \& Juan Bautista Chirivella Martorell, Departamento de Geología, Universitat de València, C/Dr. Moliner 50 E-46100 Burjasot,Spain; rodolfo.gozalo@uv.es, jchirive@xtec.cat•Jorge Esteve \& Eladio Liñán, Área y Museo de Paleontología, Departamento de Ciencias de la Tierra - Instituto Universitario de Ciencias Ambientales (IUCA), Universidad de Zaragoza, E-50009 Zaragoza, Spain; jorgeves@unizar.es, linan@unizar.es

During recent years the International Subcommission on Cambrian Stratigraphy (ISCS) has been engaged in defining new series and stages for the Cambrian System (see Peng et al. 2009). One of the most important problems facing inter-regional correlation in the Cambrian is the lack of genera and species shared between different palaeogeographic provinces. For example, many of the zonal trilobite species for Cambrian Series 3 are representatives of the family Ptychagnostidae, and the Drumian Stage was defined by Babcock et al. (2007) at the first occurrence of Ptychagnostus atavus, whereas localities in the Mediterranean subprovince (sensu Sdzuy et al. 1999; Fig. 1) do not yield any ptychagnostids. Nevertheless, a correlation between the official chronostratigraphy ISCS scale and the Mediterranean scale is needed. Therefore this correlation has to be carried out using polymeroid trilobites. Our aim is to recognize the base of Drumian Stage in the Iberian Chains (NE Spain).

Hitherto, the base of Ptychagnostus atavus Zone has been correlated with an undetermined level in the upper part of the lower Caesaraugustan (Sdzuy 1971, 1972;
Shergold \& Geyer 2003). Caesaraugustan biozonation of the Iberian Peninsula was developed originally by Sdzuy (1968). However each zone in Caesaraugustan was used with different criteria (e.g. Acme zones, assemblage zones, range zones or phylozones, see Álvaro \& Vizaïno 1998). These disagreements as to criteria make any international correlation difficult. We have worked on the revision of the Caesaraugustan zones in various sections of the Iberian Chains (northeast Spain). The new detailed samplings allow us to propose interval phylozones throughout the Caesaraugustan Stage. The sections studied are close to the villages of Murero, Jarque, Villafeliche, and Purujosa, which are located about $100 \mathrm{~km}$ west and south-west of Zaragoza, in the Aragonese branch of the Iberian Chains (Fig. 2). From a geological point of view, these localities belong to the Badules Unit (see Gozalo \& Liñán 1988).

We have studied the trilobites of the transition from lower to middle Caesaraugustan succesion from the basal part of the Murero Formation in five sections: Rambla de Valdemiedes 1 and 2 (RV1 and RV2: Liñán \& Gozalo 1986; Gozalo et al. 1996, 2003a; Chirivella Martorell 


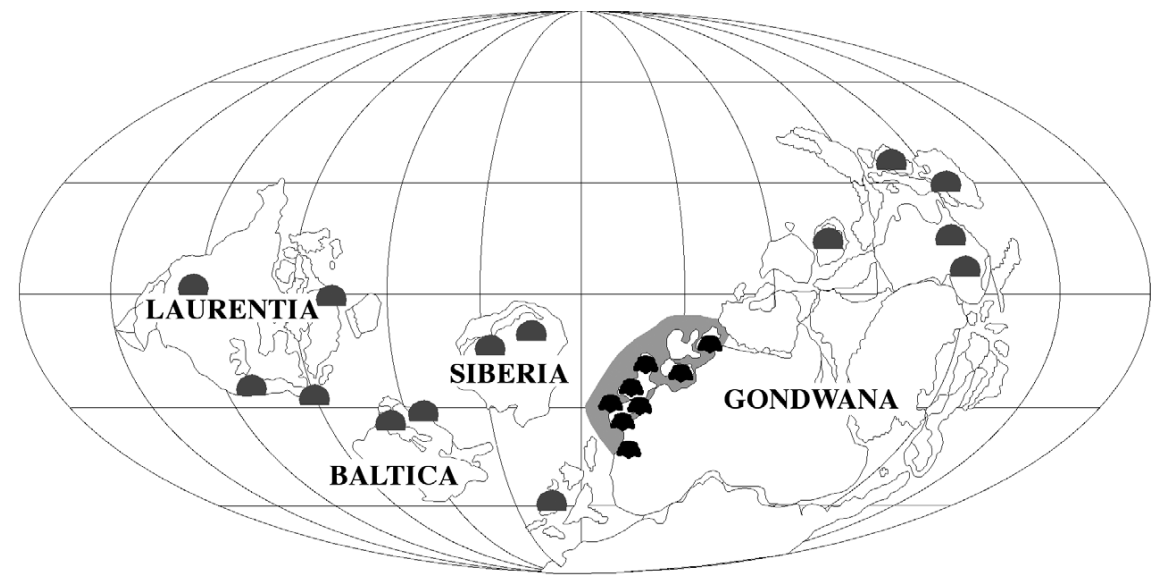

Figure 1. Distribution of Ptychagnostus atavus and Pardaihania hispida [plotted on the McKerrow et al. (1992) palaeogeographic map]. These two species have not been recorded in the same areas, Pardailhania hispida (Thoral, 1935) is restricted to the Mediterranean Subprovince in contrast to Ptychagnostus atavus (Tullberg, 1880) with a much more widespread distribution.

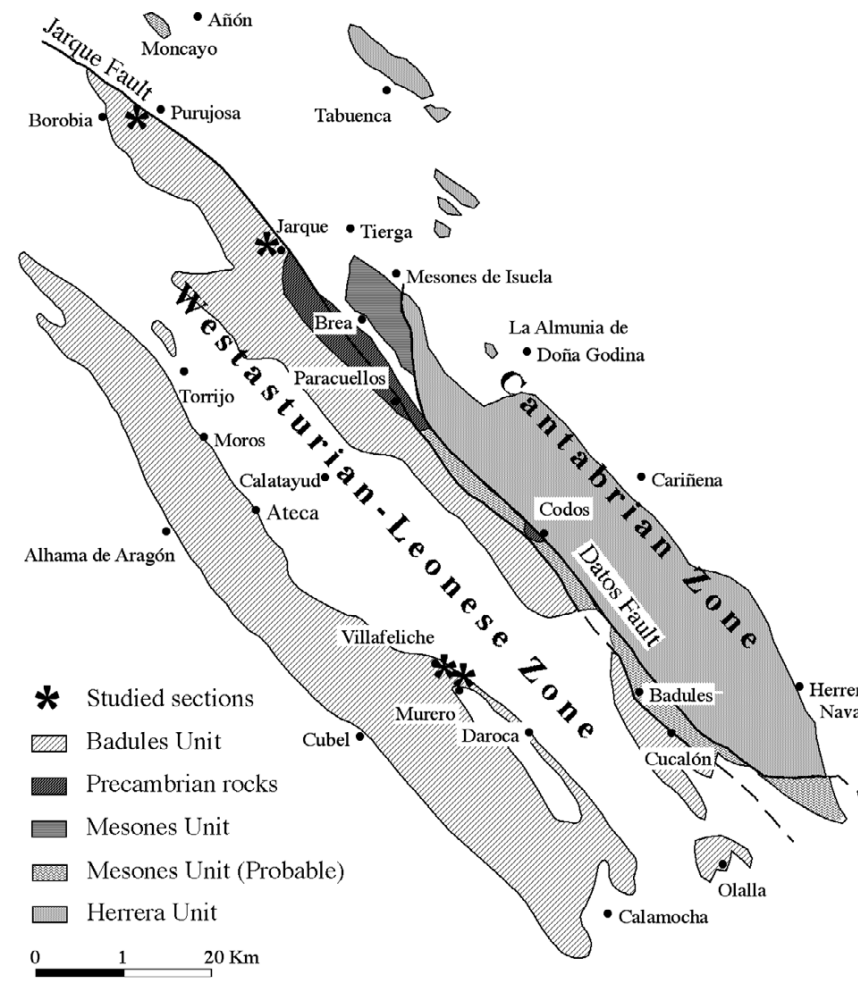

2008; Liñán et al. 2008), Jarque 1 (J1: Liñán et al. 1996, 2008, Chirivella Martorell 2008), Villafeliche 1 (Vi1: Gozalo et al. 1993, 1996; Chirivella Martorell 2008) and Purujosa 6 (Pur6, unpublished data).

\section{Biostratigraphic framework}

The classical Spanish middle Cambrian biozonation was established by Sdzuy (1968, 1971, 1972) and has been used with minor modifications until now (i.e. Liñán \& Gozalo 1986; Sdzuy et al. 1996; Álvaro \& Vizcaïno 1998; Liñán et al. 2002, 2004; Gozalo et al. 2003b, 2008; Esteve et al. 2008; Fig. 3). From a historical point of view the Mediter-

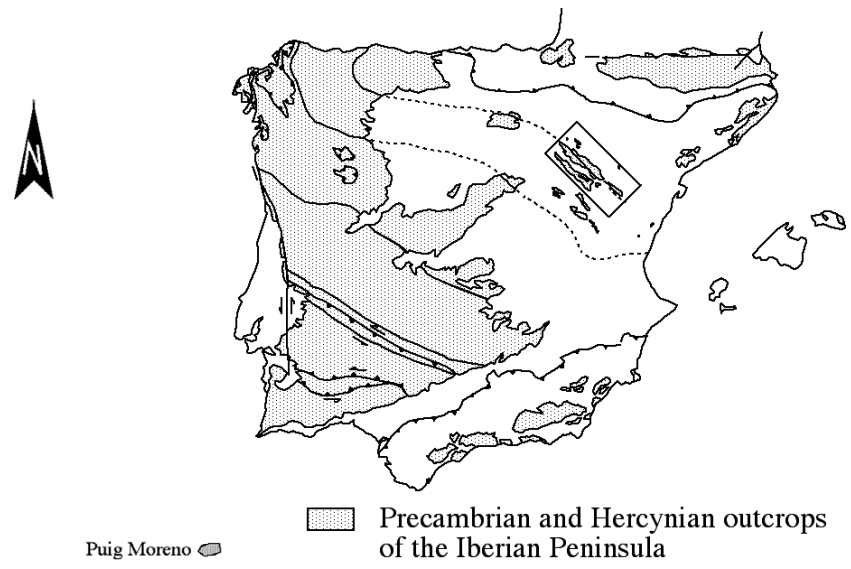

Figure 2. Geographical and geological setting of the Iberian Chains sections cited in the text (modified from Gozalo \& Liñán 1988). * - localities cited in the text. ranean zones that are involved in the base of Drumian Stage seem to correspond with the Badulesia granieri and Pardailhania hispida zones (sensu Sdzuy 1968, 1971, 1972). According to Liñán et al. (1993) the boundary between these zones also marks the lower-middle Caesaraugustan boundary.

Sdzuy $(1968,1971,1972)$ put the base of Pardailhania hispida level at the FAD of Pardailhania hispida hispida; however the older specimens of Pardailhania hispida n. spp. were recorded together with Badulesia granieri and Badulesia paschi in the previous level. Therefore the FAD of Pardailhania hispida lies lower than the former use of the $P$. hispida Zone that was used as acme zone by Sdzuy $(1968,1971,1972)$ and considered as an interval zone by 
Rodolfo Gozalo et al. - Correlation between the base of Drumian Stage and the base of middle Caesaraugustan Stage

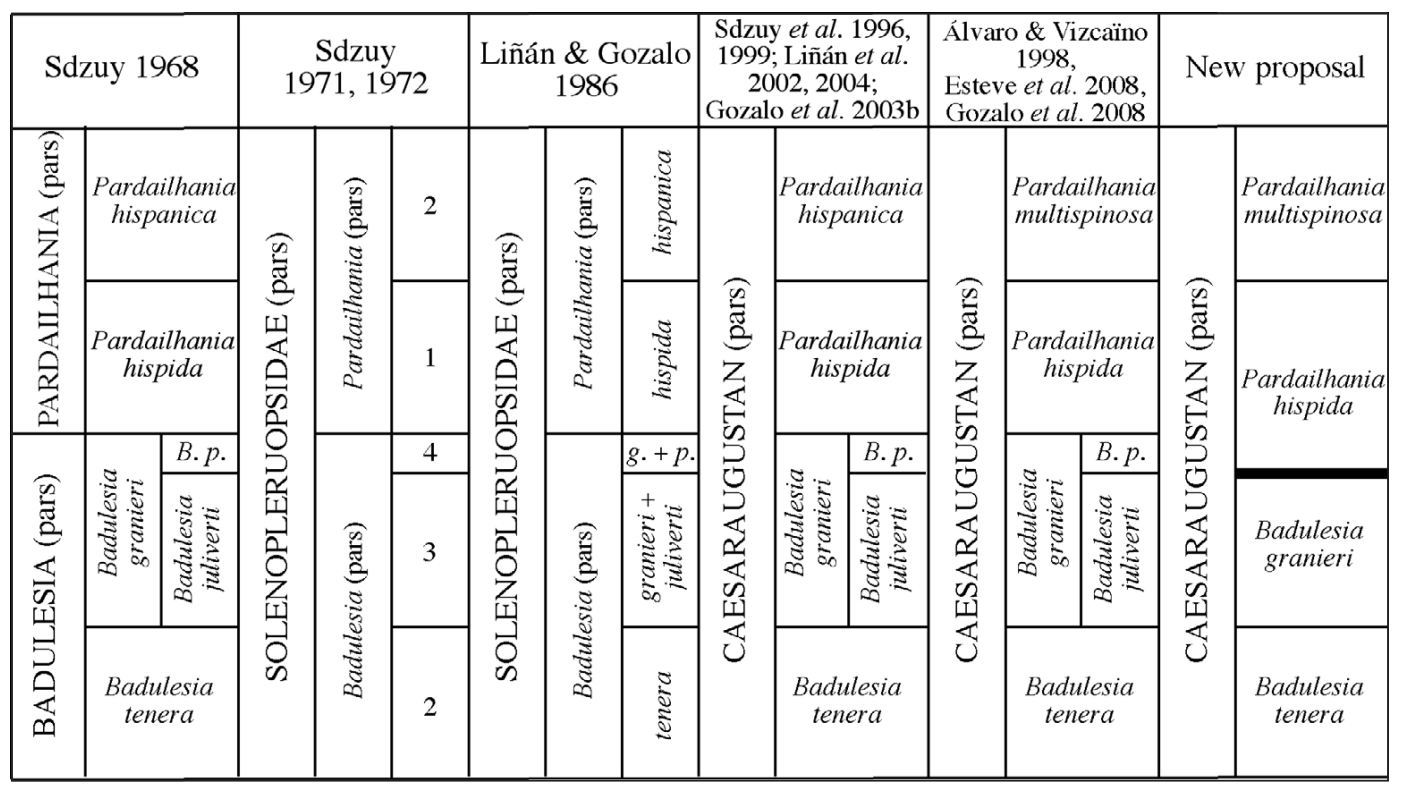

Figure 3. Sketch showing the main biostratigraphic subdivisions of the level studied in the Middle Cambrian of the Spain and France. B.p.: Badulesia paschi, g. + p.: granieri + paschi

Liñán \& Gozalo (1986), Álvaro \& Vizcaïno (1998) and others. Nevertheless they did not change the position of the lower boundary of the P. hispida Zone. The problem has been that all the researchers until now accepted the facto Sdzuy's idea about the existence of two subspecies of Pardailhania hispida; although Pardailhania hispida n. spp. never was defined and/or figured (Sdzuy 1971, table 1; 1972, table 2). Currently we accept that Pardailhania hispida has a wide and continuous morphological variation within the features of cranidia (Chirivella Martorell 2008, Esteve et al. 2008) and it is not possible to recognise two subspecies, as Sdzuy had proposed. Thus, the lower boundary of the Pardailhania hispida interval Zone should be placed at the $P$. hispida FAD, slightly below Sdzuy's original definition for the $P$. hispida Zone (Figs 3, 4). This modification of the systematic interpretation of $P$. hispida makes it necessary to redefine the Badulesia granieri and Pardailhania hispida zones.

\section{Badulesia granieri interval Zone}

Synonymy: "Nivel de B. granieri" (part.), sublevel "B. juliverti" (Sdzuy 1968). "Nivel de B. juliverti y B. granieri" (Sdzuy 1971). "Biozona Badulesia granieri + Badulesia juliverti" (Liñán \& Gozalo 1986). "Superbiozone à B. granieri" (part.) and "phylozone à B. juliverti" (Álvaro \& Vizcaïno 1998). See Fig. 3.

Our proposal is to consider this zone as an interval phylozone, the base of which coincides with the Badulesia granieri FAD and the top is the level immediately below the Pardailhania hispida FAD.
The trilobites recorded in the Iberian Chains in this time interval (see Chirivella Martorell 2008; Fig. 5) are: Peronopsis acadica, Condylopyge sp., Eccaparadoxides asturianus, E. sulcatus, E. sequeirosi, E. acadicus (Fig. 6K, L), Badulesia granieri, B. tenera, Parabailiella schmidti, P. languedocensis, Bailiella cf. tenuicincta and Ctenocephalus (Hartella) cf. terranovicus.

So far Badulesia granieri has been recorded in France (Montagne Noire: Courtessole 1973, Álvaro \& Vizcaïno 1998); in Spain (Sdzuy 1961, 1968, 1969; Liñán \& Gozalo 1986; Gámez et al. 1991; Gozalo et al. 1993; Liñán et al. 1995) and Morocco (Geyer et al. 1995, Geyer \& Landing 2006). Furthermore, it may be possible to recognise equivalent levels of this zone in Turkey and Italy, where the index taxa for the previous and/or subsequent zones have been recognized.

\section{Pardailhania hispida interval Zone}

Synonymy: "Nivel de B. granieri" (part), sublevel "B. paschi" and "Nivel de P. hispida" (Sdzuy 1968). "Nivel de B. paschi y B. granieri" and "Nivel de P. hispida" (Sdzuy 1971). "Biozona de Badulesia granieri + Badulesia juliverti" and biozona "Pardailhania hispida" (Liñán \& Gozalo 1986). "Superbiozone B. granieri", "phylozone à B. paschi" and "phylozone à P. hispida" (Álvaro \& Vizcaïno 1998). See Fig. 3.

We consider the Pardailhania hispida Zone as an interval phylozone, the base of which lies at the FAD of Pardailhania hispida and the top immediately below the FAD of Pardailhania multispinosa (see Esteve et al. 2008). 


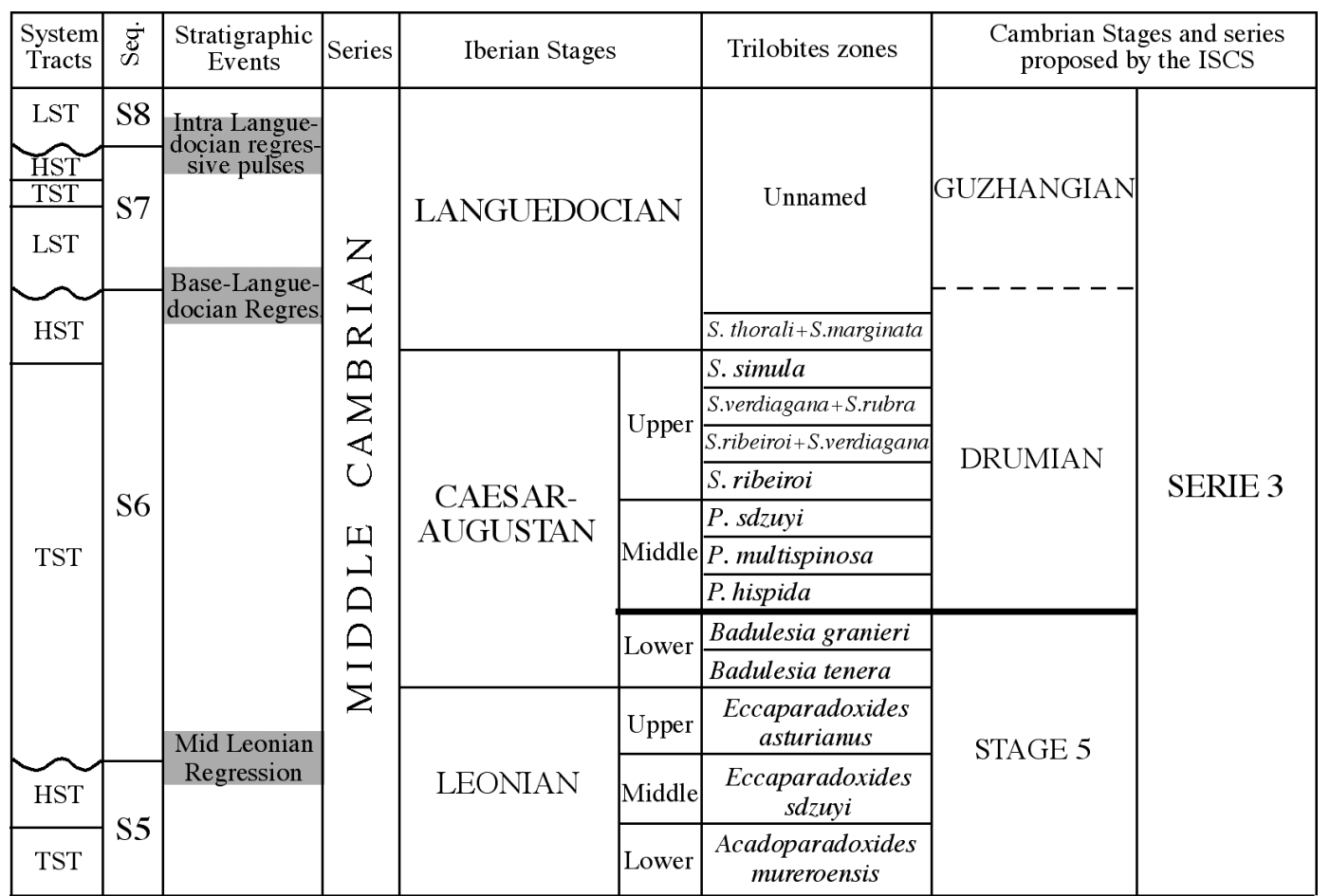

Figure 4. Middle Cambrian chronostratigraphic units for the Mediterranean Subprovince (modified from Liñán et al. 2002) and the correlation with the Cambrian Stages and Series proposed by ISCS, with a subdivision into sequences and systems tracts (from Gámez et al. 2009). Abbreviations: HST - highstand system tract; LST - lowstand system tract; TST - transgressive system tract.

Our proposal to define the $P$. hispida Zone as an interval phylozone implies that the levels with Badulesia paschi (former B. granieri + B. paschi Subzone) that occur in the top of $B$. granieri Zone (lower Caesaraugustan) currently are the base of $P$. hispida Zone (middle Caesaraugustan). The $P$. hispida Zone seems to bear the highest diversity and relative abundance of trilobites in the Iberian Chains (see Chirivella Martorell 2008; Fig. 5). At least eighteen species have been collected in the lower part: Peronopsis acadica, P. segmenta (Figs 6A-C, 7), Peronopsella westergardi, Diplagnostus planicauda (Figs 6G-I, 8), Condylopyge rex (Fig. 6D-F), Pardailhania hispida (Fig. 6M), Badulesia granieri, B. paschi, Eccaparadoxides asturianus, E. sequeirosi, E. acadicus (Fig. 6K, L), E. rouvillei (Fig. 6J), Parabailiella schmidti, P. languedocensis, Ctenocephalus (Hartella) antiquus, Agraulos longicephalus, A. arenosus and Skreiaspis miqueli. The diversity of agnostids, five species, may indicate a transgressive pulse.

So far Pardailhania hispida has been recorded in France (Montagne Noire: Thoral 1935, Courtessole 1973, Álvaro \& Vizcaïno 1997), in Spain (Sdzuy 1961, 1968; Palacios 1982; Liñán \& Gozalo 1986), in Italy (Sardinia: Rasetti 1972, Loi et al. 1995) and in Turkey (Shergold \& Sdzuy 1984; Dean 2005, 2006). In addition, Geyer et al. (1995) and Geyer \& Landing (2006) cited the presence of the genus Pardailhania in Morocco.

\section{Correlation between the base of the Drumian Stage and the base of the middle Caesaraugustan}

The classical correlation between Spain and Baltica (Sdzuy 1971, 1972) placed the base of Pardailhania within the Tomagnostus fissus and Ptychagnostus atavus Zone without further qualification, and slightly above of the Paradoxides hicksii Zone in Eastern Newfoundland. These correlations have been followed by later workers (e.g. Shergold \& Geyer 2003, Liñán et al. 2002, Gozalo et al. 2008). Recently, Fletcher $(2006$, p. 68, 2007) and Elicki \& Geyer (2010) moved this boundary below the previous proposal. They have considered that the correlation of the base of Ptychagnostus atavus Zone would be with a level just below the base of the Badulesia granieri (see Fletcher 2006, fig. 18) or with the base of Caesaraugustan (base of Badulesia tenera Zone) (see Elicki \& Geyer 2010, fig. 1). On the other hand, the redefinition of the Pardailhania hispida Zone, the lower boundary of which lies below the old Pardailhania hispida Zone (sensu Sdzuy 1971, 1972). Therefore, it is likely that the correlation of the base of Pardailhania hispida would be roughly equivalent to the base of Tomagnostus fissus and Ptychagnostus atavus Zone. This roughly corresponds to the base of Drumian Stage.

The available data reinforce this correlation. Although many of trilobite species are endemic to the Mediterranean 


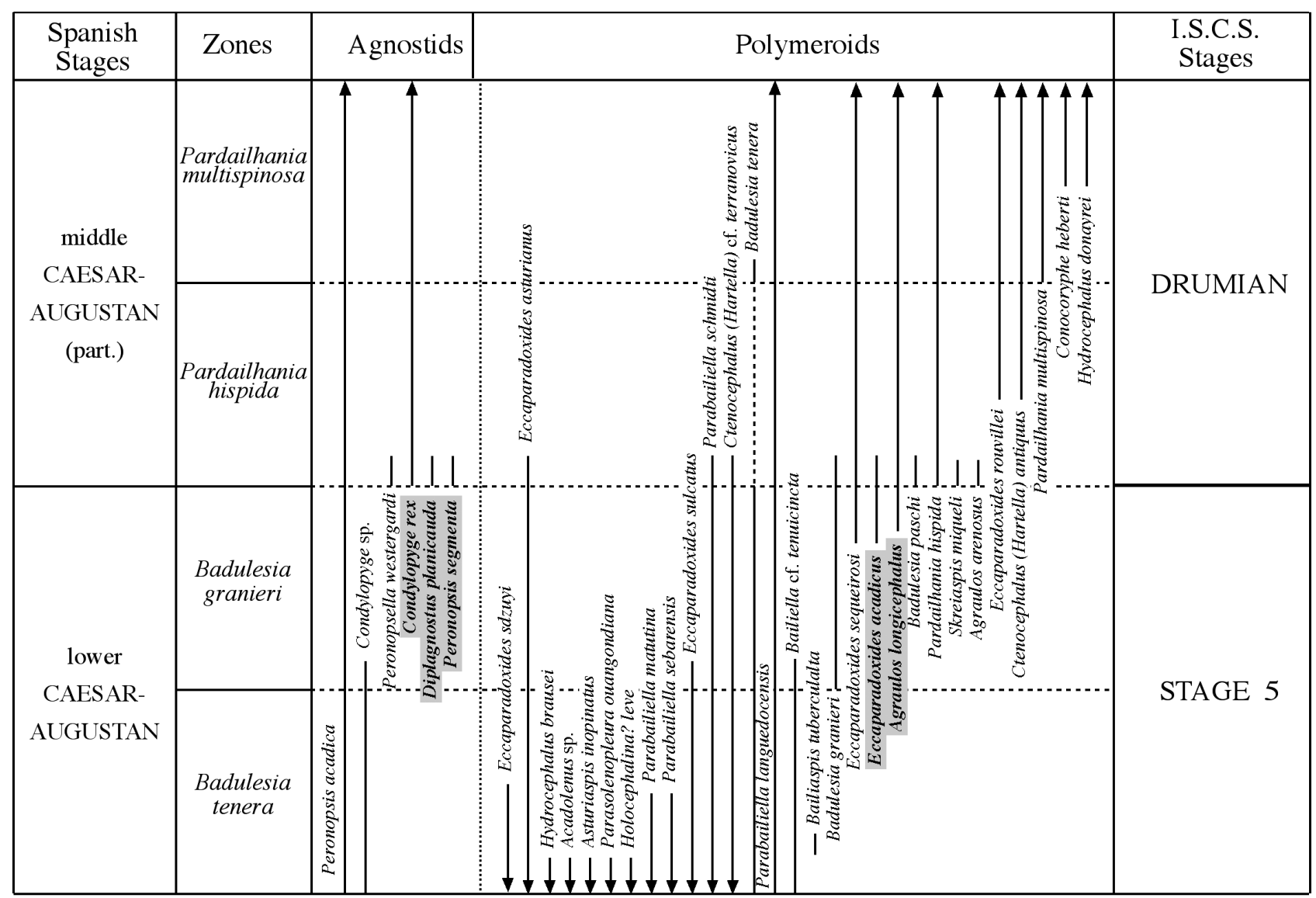

Figure 5. Stratigraphic distribution of trilobite species in the lower and middle Caesaraugustan of the Iberian Chains showing the proposed correlation with ISCS subdivision. Names of species comment in the correlation section are highlighted.

region (e.g. Badulesia granieri, Badulesia paschi, Pardailhania hispida, Eccaparadoxides sequeirosi, Parabailiella languedocensis, etc.), there are some species that have been recorded also in other palaeogeographic regions: Eccaparadoxides acadicus, Agraulos longicephalus, Diplagnostus planicauda, Peronopsis segmenta and Condylopyge rex. We discuss the biostratigraphical information of these species below.

a) Eccaparadoxides acadicus (Avalonian species) (Fig. 6K, L) whose stratigraphic range is in the Eccaparadoxides eteminicus and Hartella zones in New Brunswick and Newfoundland (Kim et al. 2002) and which was recorded from the top of the Ptychagnostus gibbus or base of the Tomagnostus fissus Zone in England (Rushton et al. 2007); thus its presence in the Pardailhania hispida Zone indicates that the youngest age for this zone would be the base of Ptychagnostus atavus Zone, which is the base of Drumian Stage.

b) Agraulos longicephalus has been recorded in Great Britain, eastern Newfoundland, Spain and France. The range in Wales is Tomagnostus fissus and Hypagnostus parvifrons zones (Thomas et al. 1984); eastern Newfoundland, Paradoxides hicksii Zone (Martin \& Dean 1988;
Fletcher 2006, 2007); Spain, Pardailhania hispida to Solenopleuropsis ribeiroi zones (Liñán \& Gozalo 1986); France, levels A1, A2 and B? (Courtessole 1973), which is equivalent to middle Caesaraugustan and upper Caesaraugustan (Álvaro \& Vizcaïno 1998). The biostratigraphical range is equivalent to Ptychagnostus atavus Zone in the sense of Peng \& Robison (2000).

c) Diplagnostus planicauda (Figs 6G-I, 8) has a wide geographic and stratigraphic distribution. Its FAD is recorded in the base of Ptychagnostus atavus Zone (Peng \& Robison 2000), thus its presence in the base of Pardailhania hispida Zone indicates that the oldest age for this zone would be Drumian.

d) Peronopsis segmenta (Figs 6A-C, 7) has been recorded only in the eastern Great Basin (Robison 1964, 1982, 1984) and the observed range is from middle Ptychagnostus gibbus to Ptychagnostus punctuosus Zone or upper part of the Cambrian Stage 5 and Drumian Stage.

e) Condylopyge rex (see Appendix 1; Fig. 6D-F) has been recorded beyond the Mediterranean region in Bohemia, Baltica, England and eastern Newfoundland where shows a wide stratigraphic range. The range in Bohemia is Eccaparadoxides pusillus to Onymagnostus hybridus 

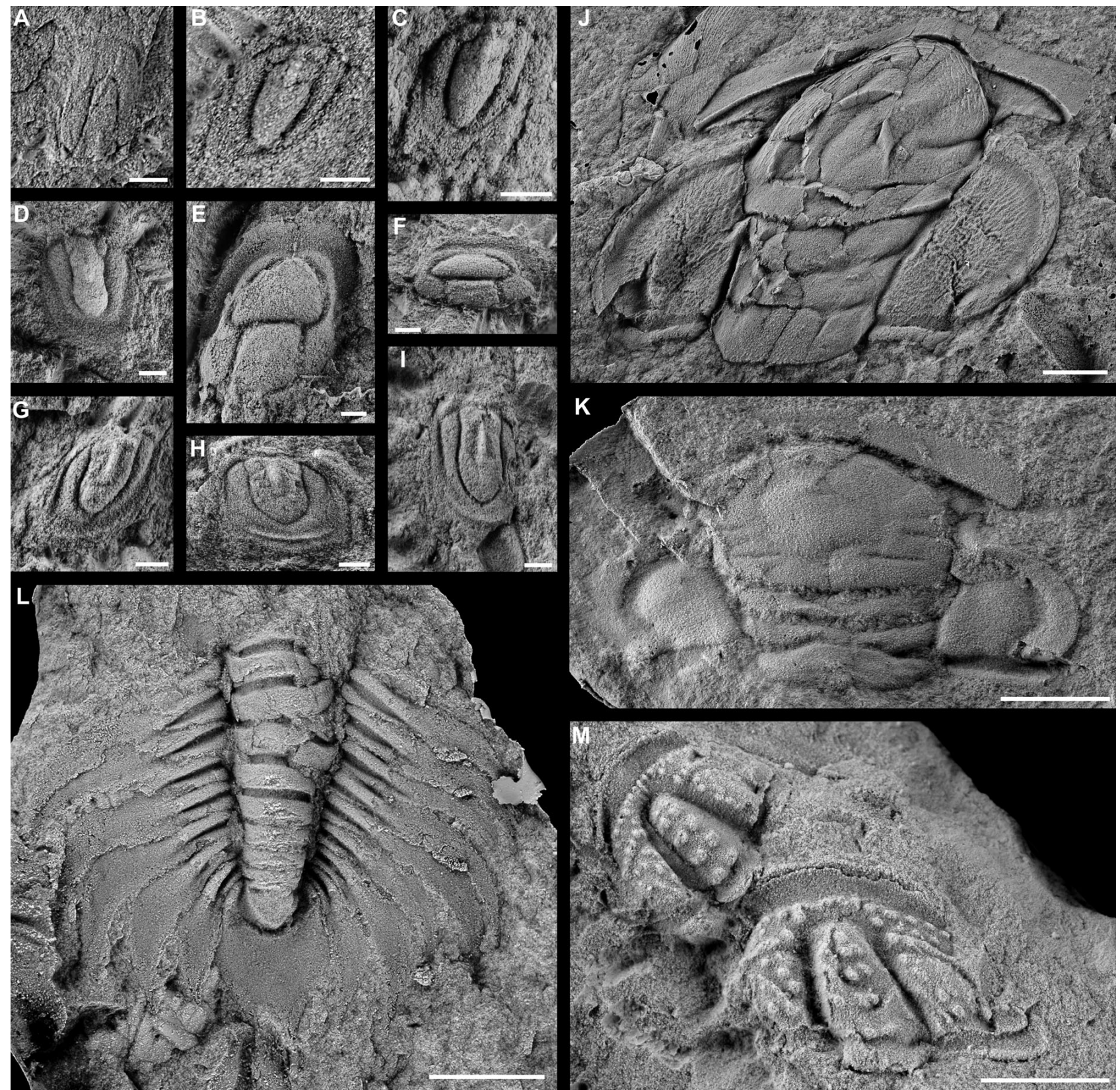

Figure 6. Trilobites of the Pardailhania hispida Zone. • A-C - Peronopsis segmenta Robison, 1964; A - cephalon, internal mould, MPZ 2007/350; B, C - pygidium, internal mould (B) and latex cast (C) of the same specimen, MPZ 2007/348. • D-F - Condylopyge rex (Barrande, 1846); D - pygidium, internal mould, MPZ 2007/456; E - cephalon, latex cast, MPZ 2007/447; F -cephalon, internal mould, MPZ 2007/461. • G-I - pygidia of Diplagnostus planicauda (Angelin, 1851); G - internal mould, MPZ 2007/422; H - latex cast, MPZ 2007/428; I - internal mould, MPZ 2007/423. • J - Eccaparadoxides rouvillei (Miquel, 1905), cranidium, latex cast MPZ 2011/78. $\bullet \mathrm{K}, \mathrm{L}$ - Eccaparadoxides acadicus (Matthew, 1883); K - cranidium, latex cast, MPZ 2007/501; L - thoracic segments and pygidium, latex cast, MPZ 2007/516. • M - cranidia of Pardailhania hispida (Thoral, 1935), latex cast, MPZ 3078 and 3079 (specimens figured by Liñán \& Gozalo 1986, pl. 24, figs 9, 10). All the specimens are housed in Museo de Paleontología de la Universidad de Zaragoza (MPZ). Scale bars: figures A-I $1 \mathrm{~mm}$, figures J-M $5 \mathrm{~mm}$.

zones (Fatka et al. 2004); in Sweden and Norway, Hypagnostus parvifrons Zone (Westergård 1946) or top of Ptychagnostus atavus Zone sensu Høyberget \& Bruton (2008); in Warwickshire, England, it occurs in the hicksii Zone (Illing 1916; Fletcher 2007, fig. 2) in beds equivalent to the Ptychagnostus gibbus and Tomagnostus fissus zones
(Rushton 1979, Thomas et al. 1984); in Spain, Pardailhania hispida to Solenopleuropsis thorali zones (Sdzuy 1961, Liñán \& Gozalo 1986, Chirivella Martorell 2008); in France, level B (Courtessole 1973) equivalent to Solenopleuropsis ribeiroi Zone (Álvaro \& Vizcaïno 1998); in Eastern Newfoundland, Paradoxides hicksii and 
P. davidis zones (Howell 1925; Hutchinson 1962; Fletcher 2006, 2007, fig. 3), and in Germany, upper part of Caesaraugustan (Sdzuy 2000). In summary the total range of this species would be from the upper part of the Ptychagnostus gibbus to the Ptychagnostus atavus zones or the upper part of the Cambrian Stage 5 and Drumian Stage.

We do not know currently whether the base of Drumian lies at a lower level. However, a comparison of the biostratigraphic ranges of these species seems to show that the best correlation of the basal level of Pardailhania hispida is likely with the basal part of the Ptychagnostus atavus Zone. Thus, the FAD of Pardailhania hispida in the Mediterranean subprovince can be used as the local index trilobite for the Drumian Stage in this region.

\section{Other data}

The biofacies analysis and the sequence stratigraphy established for the Iberian Chains (see Gámez Vintaned et al. 2009; Fig. 4) show that the basal beds of Pardailhania hispida Zone was deposited during the Transgressive System Tract of the Sequence 6. The relative abundance of agnostids and diversity of polymeroids trilobites could be indicative of a relative maximum transgressive for these levels. Likewise the basal levels of the Ptychagnostus atavus Zone in Drum Mountains [(USA Babcock et al. 2007)] are associated with a relative maximum transgressive pulse (Babcock et al. 2004, 2007). This transgressive event also supports our proposal of correlation between the bases of Pardailhania hispida and Ptychagnostus atavus zones.

Recently, Álvaro et al. (2008) on the basis of the carbon isotopic studies suggested a different correlation for the Mediterranean subprovince. They considered that a negative $\delta^{13} \mathrm{C}_{\text {org }}$ shift from a background of $-22 \%$ o to a negative peak of $-24.5 \%$ in the Campelou section Montagne Noire, France) belong to the Drumian Carbon Isotope Excursion (DICE), more or less equivalent to the base of Drumian (see Ahlberg et al. 2009, Howley \& Jiang 2010). The DICE falls in the base of middle Languedocian (of the Mediterranean scale) in the Campelou section Álvaro et al. (2008). Because the Montagne Noire and Iberian Chains share trilobite faunas, this correlation suggested that all the species listed above in the Iberian Chains have an age of Cambrian Stage 5. However the middle Languedocian in the Campelou section does not share any trilobites with areas where the DICE excursion has been detected. This disagreement between the biostratigraphic data and isotopic data could be due to various issues. Firstly, this disagreement is likely the result of low resolution, 27 samples in a section of $200 \mathrm{~m}$ thick with different intervals between samples and meter scale close to chemostratigraphic anomalies. Despite of fine sampling close to the chemostratigraphic anomalies, many negative anomalies

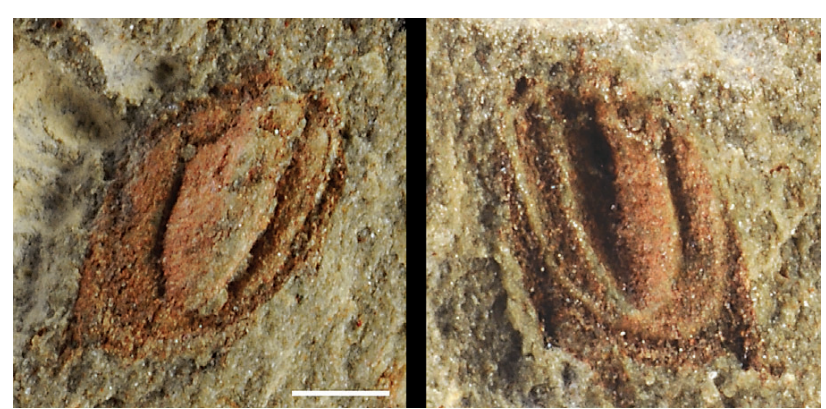

Figure 7. Pygidium of Peronopsis segmenta Robison, 1964. • A - internal mould, B - external mould of the same specimen, also figured in Fig. 6B, C, MPZ 2007/348. Scale bar $1 \mathrm{~mm}$.

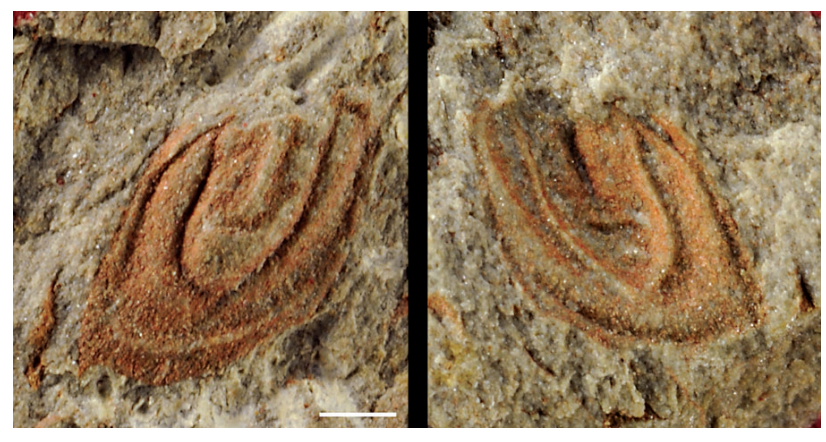

Figure 8. Pygidium of Diplagnostus planicauda (Angelin, 1851). - A - internal mould, B - external mould of the same specimen, also figured in Fig. 6G, MPZ 2007/422. Scale bar $1 \mathrm{~mm}$.

are detected in other researches close to SPICE (Montañez et al. 2000; Zhu et al. 2004, 2006). Therefore a lack of a biostratigraphical control with trilobites in the Campelou section prevents us from knowing whether this negative anomaly belongs to DICE or to a negative excursion closer to the SPICE peek. For the moment, the biostratigraphic data of Montagne Noire and Iberian Chains and their trilobitic correlation with other regions show that the negative isotope excursion considered as DICE by Álvaro et al. (2008) in the Montagne Noire really correspond with a high stratigraphic level within Drumian, not below.

\section{Conclusion}

The new data and the previous work on biostratigraphy and sequence stratigraphy demonstrate that the bases of the Pardailhania hispida and Ptychagnostus atavus zones are roughly equivalent. The FAD of Pardailhania hispida could be used in the Mediterranean region as a marker for the beginning of the Drumian Stage. This level is easily identifiable in several places: the Montagne Noire (France), Cantabrian Mountains, Demanda Mountains and Iberian Chains (Spain), Sardinia (Italy), Amanos and Sultan Mountains (Turkey), and, probably, the Antiatlas (Morocco). 


\section{Systematic appendix}

\section{Condylopyge rex (Barrande, 1846)}

Figure 6D-F

v 1986 Condylopyge aff. regia (Sjögren, 1872). - Liñán \& Gozalo, pp. 39, 40, pl. 1, fig. 9.

v 1986 Condylopyge rex rex (Barrande, 1846). - Liñán \& Gozalo, p. 40 (with previous synonym).

v 1986 Condylopyge rex hispanica n. ssp. - Liñán \& Gozalo, pp. 40, 41, pl. 1, figs 10-20 (with previous synonym).

2002 Condylopyge rex (Barrande, 1846). - Valíček \& Szabad, pp. 75, 76, pl. 1, fig. 1 (with previous synonym).

2004 Condylopyge rex (Barrande, 1846). - Buchholz, p. 516, pl. 3, figs 10, 11.

2005 Condylopyge rex (Barrande). - Cotton \& Fortey, fig. 1A.

2006 Condylopyge rex (Barrande, 1846). - Valíček, pl. 1, figs 7-9, fig. 2.

v 2008 Condylopyge rex (Barrande, 1846). - Chirivella Martorell, pp. 69-72, pl. 3, fig. 12, pl. 4, figs 1-11 (with previous synonym).

2008 Condylopyge rex (Barrande, 1846). - Høyberget \& Bruton, pp. 71, 72, pl. 12, figs $\mathrm{K}, \mathrm{M}$ (with previous synonym).

2009 Condylopyge rex. - Ahlberg, Axheimer, Babcock, Eriksson, Schmitz \& Terfelt, fig. 3G.

2009 Condylopyge rex. - Fatka \& Mergl, fig. 9e.

Comments. - Liñán \& Gozalo (1986) subdivided the species C. rex in two subspecies. They defined C. rex hispanica from Spain and France and suggested the possibility of another Scandinavian subspecies. Their main criteria were geographic and the different morphological combinations of the pygidium and cephalon borders. The Bohemian specimens have both convex borders (see Šnajdr 1958). The Mediterranean specimens have the plane cephalic border and convex pygidial border (Sdzuy 1961, Liñán \& Gozalo 1986), and the Scandinavian forms have a plane cephalic border and convex pygidial border (Westergård 1946). Also the age of the three subspecies seemed different.

The material classified as C. rex hispanica by Liñán \& Gozalo (1986) have been recorded of the upper Caesaraugustan levels. They found a similar cephalon from the base of Pardailhania hispida Zone that classified as Condylopyge aff. regia (Sjögren, 1872) because the cephalon morphology is close to this species, but the lack of pygium prevent to classify in open nomenclature. The new samplings on the level where had been found Condylopyge aff. regia by Liñán \& Gozalo (1986) allow us to find several cephala and pygidia of Condylopyge. The pygidium morphology is C. rex type, thus we assign this material to this species.

New specimens of $C$. rex have been published from Bohemian region (Valíček \& Szabad 2002, Valíček 2006) that show an important morphological variability in the cephalic and pygidial borders and increase the stratigraphic range for this species (see Fatka et al. 2004). Now the age range of Spanish specimens is similar to the Bohemian and Scandinavian specimens, and the morphological variability does not permit to recognise the different subspecies proposed by Liñán \& Gozalo (1986).

\section{Acknowledgements}

We thank Adrian W.A. Rushton and Terence P. Fletcher for their constructive reviews. This paper is a contribution to the project Consolider CGL2006-12975/BTE ("MURERO) from Ministerio de Educación y Ciencia de España. Jorge Esteve has a pre-doctoral research grant from FPI program link to Consolider CGL2006-12975 project. We thank Isabel Pérez Urresti (MEC-FEDER and Zaragoza University) for her help with the photographs.

\section{References}

AhlberG, P., Axheimer, N., BABCOCK, L.E., ErIKSSON, M.E., SCHMITZ, B. \& TERFELT, F. 2009. Cambrian high-resolution biostratigraphy and carbon isotope chemostratigraphy in Scania, Sweden: first record of SPICE and DICE excursions in Scandinavia. Lethaia 42, 2-16.

DOI 10.1111/j.1502-3931.2008.00127.X

Álvaro, J.J., BAuluz, B., SubÍAS, I., Pierre, C. \& VizCaÏNO, D. 2008. Carbon chemostratigraphy of the Cambrian-Ordovician transition in a midlatitude mixed platform, Montagne Noire, France. Geological Society of America Bulletin 120, 962-975. DOI 10.1130/B26243.1

Álvaro, J.J. \& VIZCAÏNO, D. 1997. Révision des Trilobites Solenopleuropsinae du Cambrien moyen de la Montagne Noire (France). Geobios 30, 541-561. DOI 10.1016/S0016-6995(97)80121-0

ÁlVARO, J.J. \& VIZCAÏNO, D. 1998. Révision biostratigraphique du Cambrien moyen du versant méridional de la Montagne Noire (Languedoc, France). Bulletin de la Société Géologique de France 169, 233-242.

Angelin, N.P. 1851. Palceontologica Svecica. Pars I; Iconographia crustaceorum formationis transitionis. 24 pp. Academie Regiae Scientarium Suecanae, Holmiae (Stockholm).

BABCOCK, L.E., REES, M.N., ROBISON, R.A., LANGENBURG, E.S. \& PENG, S.C. 2004. Potential Global Stratotype-section and Point (GSSP) for a Cambrian stage boundary defined by the first appearance of the trilobite Ptychagnostus atavus, Drum Mountains, Utah, USA. Geobios 37, 149-158. DOI 10.1016/j.geobios.2003.03.007

BABCOCK, L.E., RoBisOn, R.A., REES, M.N., PENG, S. \& SALTZMAN, M.R. 2007. The Global boundary Stratotype Section and Point (GSSP) of the Drumian stage (Cambrian) in the Drum Mountains, Utah, USA. Episodes 30, 84-94.

BARRANDE, J. 1846. Notice préliminaire sur le système silurien et les trilobites de Bohême. vi + 96 pp. Hirschfeld, Leipzig.

BuCHHOLZ, A. 2004. Ein Geschiebe der Hypagnostus parvifrons-Zone (Mittelkambrium B3) mit feinstratigraphischer Schichtun und seltenen sowie neuen Trilobiten. Archiv für Geschiebekunde 3 (8/12), 501-524. 
ChiRivella Martorell, J.B. 2008. Sistemática de los Trilobites, bioestratigrafía y paleoecología del límite LeonienseCaesaraugustiense (Cámbrico medio) en las Cadenas Ibéricas (NE de España). 226 pp. Doctoral thesis, Universitat de València, Spain (unpublished).

COURTESSOLE, R. 1973. Le Cambrien Moyen de la Montagne Noire. Biostratigraphie. 248 pp. Imprim. d'Oc, Toulousse.

COTTON, T.J. \& FORTEY, R.A. 2005. Comparative morphology and relationships of the Agnostida, 95-136. In KoEnemann, S. \& JENNER, R. (eds) Crustacea and arthropod relationships. Crustacean Issues 16.

DEAN, W.T. 2005. Trilobites from the Çal Tepe Formation (Cambrian), Near Seydisehir, Central Taurides, Southwestern Turkey. Turkish Journal of Earth Sciences 14, 1-71.

DEAN, W.T. 2006. Cambrian Stratigraphy and Trilobites of the Samur Dag Area, South of Hakkâri, Southeastern Turkey. Turkish Journal of Earth Sciences 15, 225-257.

EliCKI, O. \& GEYER, G. 2010. Cambrian biostratigraphy, 103-114. In Linnemann, U. \& Romer, R.L. (eds) Pre-Mesozoic Geology of Saxo-Thuringia - From the Cadomian Active Margin to the Variscan Orogen. Schweizerbart, Stuttgart.

ESTEVE, J., GOZALO, R., LIÑÁN, E. \& CHIRIVELla MARTORELL, J.B. 2008. Pardailhania Thoral, 1947 (Solenopleuropsinae, Trilobita) from Caesaraugustan (Middle Cambrian) of the Iberian Chains (NE Spain), 99-103. In RÁBANO, I., GOZALO, R. \& GARCIA-BELLIDO, D. (eds) Advances in Trilobite Research. Cuadernos del Museo Geominero 9. Instituto Geológico y Minero de España, Madrid.

FAtKa, O., KoRDule, V. \& SZABAD, M. 2004. Stratigraphical distribution of Cambrian fossils in the Příbram-Jince Basin (Barrandian area, Czech Republic). Senckebergiana lethaea 84, 367-381.

FATKA, O. \& MERgL, M. 2009. The 'microcontinent' Perunica: status and story 15 years after conception. Geological Society of London, Special Publications 325, 65-101.

FLETCHER, T.P. 2006. Bedrock geology of the Cape St. Mary's Peninsula, southwest Avalon Peninsula, Newfoundland (includes parts of NTS maps sheets $1 M / 1,1 N / 4,1 L / 6$ and $1 K / 13$ ), Newfoundland. 117 pp. Report 06-02, Goverment of Newfoundland and Labrador, Geological Survey, Department of Natural Resources, St. John's.

FLETCHER, T.P. 2007. Correlating the zones of 'Paradoxides hicksii' and 'Paradoxides davidis' in Cambrian Series 3. Memoirs of the Association of Australasian Palaeontologists 33, 35-56.

GÁMEZ, J.A., FERNÁNDEZ-NIETO, C., GOZALO, R., LiÑÁN, E., MANDADO, J. \& PALACIOS, T. 1991. Bioestratigrafía y evolución ambiental del Cámbrico de Borobia (Provincia de Soria, Cadena Ibérica Oriental). Cuadernos do Laboratorio Xeolóxico de Laxe 16, 251-271.

GÁMEZ VinTANED, J.A., SCHMITZ, U. \& LiÑÁN, E. 2009. Upper Vendian-lowest Ordovician sequences of the western Gondwana margin, NE Spain, 231-244. In CRAIG, J., THUROW, J., Thusu, B., Whitham, A. \& AButarruma, Y. (eds) Global Neoproterozoic Petroleum Systems: The Emerging Potential in North Africa. Geological Society of London, Special Publications 326.

GEYER, G. \& LANDING, E. 2006. Edicaran-Cambrian depositional environments and stratigraphy of the western Atlas regions. Beringeria, Special Issue 6, 47-112.

GeYer, G., LANDING, E. \& HeldMAIER, W. 1995. Faunas and depositional environments of the Cambrian of the Moroccan Atlas regions. Beringeria, Special Issue 2, 47-119.

GOZALO, R. \& LIÑÁN, E. 1988. Los materiales hercínicos de la Cordillera Ibérica en el contexto del Macizo Ibérico. Estudios geológicos 44, 399-404.
GOZALO, R., LIÑÁN, E. \& ÁlVARO, J. 1993. Bioestratigrafía del Cámbrico Medio de Villafeliche (Prov. Zaragoza, España). Revista Española de Paleontología n ${ }^{\circ}$. extr., 49-57.

GOZALO, R., LIÑÁN, E. \& DIES, M.E. 2003a. Intraspecific dimorphism in an evolutionary series of paradoxidids from the Middle Cambrian of Murero, Spain. Special Papers in Palaeontology $70,141-156$.

GOZALO, R., LiÑÁN, E., GÁMEZ VinTANED, J.A., DiES ÁlVAREZ, M.E., ChIRIVELla MARTORELL, J.B., ZAMORA, S., ESTEVE, J. \& MAYORAL, E. 2008. The Cambrian of the Cadenas Ibericas (NE Spain) and its trilobites, 137-151. In RÁBANO, I., GOZALO, R. \& GARCIA-BELlido, D. (eds) Advances in Trilobite Research. Cuadernos del Museo Geominero 9. Instituto Geológico y Minero de España, Madrid.

GoZAlo, R., LiÑÁn, E., PALACios, T., GÁmEZ VinTANED, J.A. \& MAYORAL, E. 2003b. The Cambrian of the Iberian Peninsula: an overview. Geologica Acta 1, 103-112. DOI 10.1344/105.000001596

GoZAlo, R., LiÑÁn, E. \& SDZuY, K. 1996. September 20. The Lower and Middle Cambrian of Murero and Villafeliche (West Asturian-Leonese Zone. Western Iberian Chain), 73-80. In LIÑÁN, E., GÁMEZ VINTANED, J.A. \& GoZALO, R. (eds) II Field Conference of the Cambrian Stage Subdivision Working Groups. International Subcommission on Cambrian Stratigraphy. Spain, 13-21 September 1996. Field Trip Guide and Abstracts. Universidad de Zaragoza, Zaragoza.

Howell, B.F. 1925. Faunas of the Cambrian Paradoxides Beds at Manuels, Newfoundland. Bulletins of American Paleontology 11(43), 1-140.

Howley, R.A. \& JiANG, G. 2010. The Cambrian Drumian carbon isotope excursion (DICE) in the Great Basin, western United States. Palaeogeography, Palaeoclimatology, Palaeoecology 296, 138-150. DOI 10.1016/j.palaeo.2010.07.001

HøyBerget, M. \& BRUTON, D. L. 2008. Middle Cambrian trilobites of the suborders Agnostina and Eodiscina from the Oslo Region, Norway. Palaeontographica, Abteilung A 286, 1-87.

HutCHINSON, R.D. 1962. Cambrian stratigraphy and Trilobite faunas of southeastern Newfoundland. Geological Survey of Canada, Bulletin 88, 1-165.

ILLING, V.C. 1916. The paradoxidian fauna of a part of the Stockingford Shales. Quarterly Journal of the Geological Society of London 71 (for 1915), 386-450.

KiM, D.H., WeSTROP, S.R. \& LANDING, E. 2002. Middle Cambrian (Acadian series) conocoryphid and paradoxidid trilobites from the Upper Chamberlain's Brook Formation, Newfounland and New Brunswick. Journal of Paleontology 76, 822-842. DOI 10.1666/0022-3360(2002)076<0822:MCASCA >2.0.CO;2

LiÑÁN, E., ÁlVARO, J.J., GOZALO, R., GÁMEZ-VINTANED, J.A. \& Palacios, T. 1995. El Cámbrico Medio de la Sierra de Córdoba (Ossa-Morena, S de España): trilobites y paleoicnología. Implicaciones bioestratigráficas y paleoambientales. Revista Española de Paleontología 10, 219-238.

LIÑÁN, E. \& GOZALO, R. 1986. Trilobites del Cámbrico inferior y medio de Murero (Cordillera Ibérica). Memorias del Museo Paleontológico de la Universidad de Zaragoza 2, 1-104.

LiÑán, E., GOZAlo, R., Dies Álvarez, M.E., GÁMEZ ViNTANED, J.A., MAYORAL, E., ChIRIVElla MARTORELl, J.B., ESTEVE, J., ZAMORA, S., ZHURAVLEV, A.Y. \& ANDRÉS, J.A. 2008. Fourth International Trilobite Conference Trilo 08 Toledo, Spain, 2008. Post- Conference Field Trip. Lower and Middle Cambrian trilobites of selected localities in Cadenas Ibéricas (NE Spain). 52 pp. Universidad de Zaragoza, Zaragoza.

LiÑÁN, E., GoZalo, R., PAlacios, T., GÁMEZ VinANED, J.A., UGIDOS, J.M. \& MAYORAL, E. 2002. Cambrian, 17-29. In GIB- 
BONS, W. \& MORENO, T. (eds) The Geology of Spain. Geological Society, London.

LiÑÁn, E., Perejón, A., Gozalo, R., Moreno-Eiris, E. \& OliVEIRA, J.T. de 2004. The Cambrian System in Iberia. Cuadernos del Museo Geominero 3, 1-63.

LiÑÁn, E., PEREJón, A. \& SDZuY, K. 1993. The Lower-Middle Cambrian stages and stratotypes from the Iberian Peninsula: a revision. Geological Magazine 130, 817-833. DOI 10.1017/S0016756800023189

LiÑÁN, E., SDZUY, K., ÁLVARO, J.J., GÁMEZ VinTANED, J.A. \& GoZALO, R. 1996. September 19. The Jarque section: Lower and Middle Cambrian (West Asturian-Leonese Zone. Eastern Iberian Chain), 57-72. In LIÑÁN, E., GÁMEZ VINTANED, J.A. \& GOZALO, R. (eds) II Field Conference of the Cambrian Stage Subdivision Working Groups. International Subcommission on Cambrian Stratigraphy. Spain, 13-21 September 1996. Field Trip Guide and Abstracts. Universidad de Zaragoza, Zaragoza.

LoI, A., Pillola, G.L. \& LeONE, F. 1995. The Cambrian and Early Ordovician of south-western Sardinia. Rediconti del Seminario della Facoltà di Scienze dell'Univeristà di Cagliari, Suppl. 65, 61-81.

MARTIN, F. \& DEAN, W.T. 1988. Middle and Upper Cambrian acritarch and trilobite zonation at Manuels River and Random island, Eastern Newfoundland. Geological Survey of Canada, Bulletin 381, 1-91.

MATTHEW, G.F. 1883. Illustrations of the fauna of the St. John Group. No. 1 - The Paradoxides. Transactions of the Royal Society of Canada 1(4), 271-279.

MCKERROW, W.S., SCOTESE, C.R. \& BRASIER, M.D. 1992. Early Cambrian continental reconstructions. Journal of the Geological Society of London 149, 599-606. DOI 10.1144/gsigs.149.4.0599

Miquel, J. 1905. Essai sur le Cambrien de la Montagne Noire. Coulouma - l'Acadien. Bulletin de la Société Géologique de France, $4^{\text {eme }}$ série 5, 465-483.

MONTAÑEZ, I.P., OSLEGER, D.A., BANNER, J.L., MACK, L.E. \& Musgrove, M. 2000. Evolution of the $\mathrm{Sr}$ and C Isotope Composition of Cambrian Oceans. GSA Today 10(5), 1-7.

PalaCios, T. 1982. El Cámbrico entre Viniegra de Abajo y Mansilla (Sierra de la Demanda, Logroño). Trilobites e icnofósiles. 85 pp. Biblioteca de Estudios Riojanos, Logroño.

Peng, S., BABCOCK, L.E., ZuO, J., LIN, H., ZHU, X., YANG, X., RoBison, R.A., QI, Y., BAgnoli, G. \& CHEN, Y. 2009. The Global Boundary Stratotype Section and Point (GSSP) of the Guzhangian Stage (Cambrian) in the Wuling Mountains, Northwestern Hunan, China. Episodes 32, 41-55.

PENG, S. \& ROBISON, R.A. 2000. Agnostid biostratigraphy across the Middle-Upper Cambrian boundary in Hunan, China. Journal of Paleontology, The Paleontological Society Memoir 53, $1-104$.

RASETTI, F. 1972. Cambrian trilobite faunas of Sardinia. Atti della Accademia Nazionale dei Lincei, Memoire 8(11), 1-98.

ROBISON, R.A. 1964. Late Middle Cambrian faunas from western Utah. Journal of Paleontology 38, 510-566.

RoBISON, R.A. 1982. Some Middle Cambrian Agnostoid Trilobites from western North America. Journal of Paleontology 56 , 132-160.

RoBISON, R.A. 1984. Cambrian Agnostida of North America and Greenland. Part I, Ptychagnostidae. The University of Kansas Paleontological Contributions 109, 1-59.

Rushton, A.W.A. 1979. A review of the Middle Cambrian Agnostida from the Abbey Shales, England. Alcheringa 3, 43-61. DOI 10.1080/03115517908565439

RUSHTON, A.W.A, WILliAMS, M., SIVETER, D.J. \& BERG-MADSEN, V. 2007. A new mid-Cambrian trilobite fauna from Shropshire. Proceedings of the Geologists' Association 118, 129-142.

SDZUY, K. 1961. Das Kambrium Spaniens. Teil II: Trilobiten. Akademie der Wissenschaften und der Literatur, Abhandlungen der mathematisch-naturwissenschaftlichen Klasse 1961(7-8), 217-408.

SDZUY, K. 1968. Trilobites del Cámbrico Medio de Asturias. Trabajos de Geología, Universidad de Oviedo 1 (for 1967), 77-133.

SDZUY, K. 1969. Biostratigrafía de la Griotte Cámbrica de los Barrios de Luna (León) y de otros sucesiones comparables. Trabajos de Geología, Universidad de Oviedo 2 (for 1968), 45-68.

SDZUY, K. 1971. La subdivisión bioestratigráfica y la correlación del Cámbrico Medio de España. I Congreso Hispano-LusoAmericano de Geología Económica, Sección 1, Geología 2, 769-782.

SDZUY, K. 1972. Das Kambrium der acadobaltischen Faunenprovinz. Zentralblatt für Geologie und Paläontologie, Teil II(1972), 1-91.

SDZUY, K. 2000. Das Kambrium des Fankenwaldes. 3. Die Lippertsgrüner Schichten und ihre Fauna. Senckenbergiana lethaea 79, 301-328.

SDZUY, K., LIÑÁN, E. \& GoZALO, R. 1996. The Middle Cambrian Series, 16-18. In LiÑán, E., GÁMEZ VinTANED, J.A. \& GozAlo, R. (eds) II Field Conference of the Cambrian Stage Subdivision Working Groups. International Subcommission on Cambrian Stratigraphy. Spain, 13-21 September 1996. Field Trip Guide and Abstracts. Universidad de Zaragoza, Zaragoza.

SDZUY, K., LIÑÁN, E. \& GoZALO, R. 1999. The Leonian Stage (early Middle Cambrian): a unit for Cambrian correlation in the Mediterranean subprovince. Geological Magazine 136, 39-48. DOI 10.1017/S0016756899002241

SHERGOLD, J.H. \& GEYER, G. 2003. The Subcommission on Cambrian Stratigraphy: the status quo. Geologica Acta 1, 5-9. DOI 10.1344/105.000001588

SHERGOLD, J.H. \& SDZUY, K. 1984. Cambrian and Early Tremadocian trilobites from Sultan Dag, Central Turkey. Senckenbergiana lethaea 65, 51-135.

SJÖGREN, A. 1872. Om några försteningar i Ölands kambriska lager. Geologiska Foereningens i Stockholm Forhandlingar 1, 67-85.

ŠNAJDR, M. 1958. Trilobiti českého středního kambria. Rozpravy Ústředního ústavu geologického 24, 1-280.

THOMAs, A.T., OwENS, R.M. \& RUSHTON, A.W.A. 1984. Trilobites in British stratigraphy. 78 pp. Geological Society of London, Special Report 16.

THORAL, M. 1935. Contribution à l'étude paléontologique de l'Ordovicien inférieur de la Montagne Noire et révision sommaire de la faune cambrienne de la Montagne Noire. 362 pp. Imprimerie de la Charité, Montpellier.

VALÍČEK, J. 2006. A new agnostid trilobite from the Skryje-Týřovice area (Middle Cambrian, Jince Formation, Barrandian area, Czech Republic). Palaeontologia Bohemiae 10, 43-46.

VALÍČEK, J. \& SZABAD, M. 2002. Revision early Middle Cambrian trilobite fauna from Bohemia. Palaeontologia Bohemiae $8,75-98$.

WeSTERGÅRD, A.H. 1946. Agnostidea of the Middle Cambrian of Sweden. Sveriges Geologiska Undersökning, ser. C 477, 1-110.

ZHU, M.-Y., BABCOCK, L.E. \& PENG, S.-C. 2006. Advances in Cambrian stratigraphy and paleontology: Integrating correlation techniques, paleobiology, taphonomy and paleoenvironmental reconstruction. Palaeoworld 15, 217-222. DOI 10.1016/j.palwor.2006.10.016

ZHU, M.-Y., ZHANG, J.-M., LI, G.-X. \& YANG, A.-H. 2004. Evolution of $\mathrm{C}$ isotopes in the Cambrian of China: implications for Cambrian subdivision and trilobite mass extinctions. Geobios 37, 287-301. DOI 10.1016/j.geobios.2003.06.001 